\title{
AN ANALYSIS OF DEIXIS AND SPEECH ACT USED IN ENGLISH TEACHING AND LEARNING PROCESS
}

\author{
Yulfi $^{1}$ \\ STKIP PGRI Lubuklinggau \\ yulfie_patmo@yahoo.com ${ }^{1}$
}

Submit, 08-11-2017 Accepted, 30-12-2017 Publish, 30-12-2017

\begin{abstract}
This study focuses on analyzing deixis and speech acts used by the English teacher and eleventh grade students of language program at Islamic Integrated Senior High School Curup in the academic year 2013/2014. The topic was chosen by the researcher as the object of the research, first of all because deixis and speech acts are commonly analyzed in the daily conversation such as in movie and comic. Secondly, this school is the one that has a language program class at eleventh grade besides two science program classes and two social program classes. This study means to explain the used of deixis and speech acts in English teaching and learning. The design of this research is an ethnography research and the main instrument of this research is the researcher itself. The finding of this study shows that the teacher of English and students used deixis in their daily activity in the classroom. However, the most frequently types of deixis used by them is person deixis. Further, the most dominant type of speech acts on English teaching and learning at this class is directive utterance. Generally, the teacher more often used them to give command, suggestion and request.The teacher and students used deixis and speech acts almost in every moment. Because this class used teacher center, so the students used deixis and speech act only when they responded the teacher's questions.
\end{abstract}

Keywords: deixis, speech acts, directive utterance, person deixis.

\section{INTRODUCTION}

Very often in many interactions between teachers and students in the classroom, students cannot understand what teacher says if they do not understand the context. Some utterances produced by students also cannot be understood by teachers if they do not know who is speaking, about whom, where and when. For example when a teacher explains in front of the class then she says "I was disappointed that you did not come yesterday afternoon. I hope you will join our course this afternoon". People will not be able to identify the referents of I, you, us, yesterday afternoon and this afternoon though we understand how the first three and the last two are related to one another; because they know English, they know know, for example, that the referent of is a part of referent of them and they 
know the time sequence of yesterday afternoon and this afternoon. The meaning of any lexeme depends to some extent on the context in which it occurs, but deictic elements can only be interpreted through their context.

According to McCarty (1991:6), without understanding the physical context and linguistics context of utterances, teachers or students will lose what the speaker means. The goal of someone produces an utterance is considered good and right if it is used in appropriate context. The meaning of words in utterances or written text can be known from its context.

The word which can be interpreted its meaning based on the context is called deictic or deixis. Deixis is also a word which its referent always moves depending on the time and space of uttering the word. It is also stated that deixis is a part of pragmatics that has connection with certain word or sentence that changes because of the context. The change of context is a sentence often caused by the change of situation including personal, time and place (Levinson,1983:9). Deixis concerns the ways in which language encode features of the context of utterance or speech event, and thus also concerns ways in the interpretation of utterances on the analysis of that context on utterance.

So far, applied linguists and language teachers have been familiar with the term function for years now. Are we not simply talking about 'functions' when analyzing what a teacher and students talk in the classroom? In one sense we are talking about 'functions': we are concerned as much with what teachers and students are doing with language as with what they are saying. A request, an instruction or an exemplification as a particular bit of speech or writing, we are concentrating on what that piece of language is doing (locutionary act), or how the listener or reader is supposed to react (illocutionary) or the effect got by listener or reader after hearing or reading an utterance, many linguists call it as speech act (McCarty,1991:9).

Research on the relationship between form and function has been greatly influenced by speech act theory. Rankema (1993:21) states that in speech act theory, language is seen as a form of acting. Speech act theory has had a strong influence on the field of discourse studies as this theory focuses on the question of what people are doing when they use language.

This study deals with classroom discourse since it is relevant to various important phenomena of language use, text and conversational interactions or communication events in the classroom. It is in line with what McCarty (1991:105) states that the advantage of writing discourse analysis to investigate classroom in interaction is that it allows researchers to gain insight into what is being accomplished in a particular classroom interaction that takes place in a specific social context. 
Finally, ethnography was used in this study because it attempts to obtain an emic perspective and holistic view of what a teacher and students say and do, in order to gain a fuller representation of what is going on in the classroom. Ethnographic research combines participant observation and many of the characteristics of nonparticipant observation studies in attempt to obtain as holistic a picture as possible of a particular society, group, institution, setting or situation.

This research is very important to be done. By doing this research, people understand the meaning of deixis and speech acts produced by the English teacher and students in the classroom easily.

From the description above, the writer is interested to do a research entitled: "An Analysis of Deixisand Speech Acts Used in English Teaching and Learning Process".

\section{LITERATURE REVIEW}

Yule (1996:9) states that deixis is derived from the Greek"deicticos" means "to show" or "to indicate". It means pointing via language. Deictic terms are used to refer to ourselves to others and object in our environment. Yule (1990:129-133) says

"They are used to locate actions in a time frame relative to the present. Deictic terms show social relationship the social location individuals in relation to others. They are also used to locate parts of text in relation to other parts. Furthermore deixis concerns the ways in which language encode or grammatical features of the context of utterance or speech event. It is also concern with way in which interpretation of utterance depends on the analysis of that context of utterance."

There are some words in the language that cannot be interpreted at all unless the physical context, especially the physical context of the speaker, is known. These are words like here, there, this, that, as well as most pronouns such as $I$, he, us, it. Some sentences of English are virtually impossible to be understood if we do not know who is speaking, about whom, where and when.

Deixis also deals with connections between discourse and the situation in which discourse is used (Rankema,1993:76). The word 'deixis' is used to devote those elements in a language which refer directly to the situation. Rankema (1993:77) also says that deictic words are words with a reference point which is a speaker or writer says and is determined by the speaker's or writer's position in space and time.

Yule (1996:9) also writes that deictic expressions are also sometimes called 'indexicals'. They are among the first forms to be spoken by very young 
children and can be used to indicate people via person deixis (e.g. me, you), or location via spatial deixis (here, there), or time via temporal deixis (now, then).

Deixis is clearly a form of referring that is tied to the speaker's context, with the most basic distinction between deictic expressions being near speaker versus away from the speaker.Yule (1996:9) argues

In English, near speaker called proximal terms, are 'this', 'here', 'now'. The away from the speaker, or distal terms, are 'that', 'then', Proximal terms are typically interpreted in terms of the speaker's location, or the deictic center, so that 'now' is generally understood as referring to some point or period in time that has the time of the speaker's utterance at its center. Distal terms can simply indicate 'away from speaker', but, in some languages, can be used to distinguish between 'near addressees' and 'away from the both speaker and addressee'

Based on previous definitions, it can be concluded that deixis refers to a word in which it's referred or its pointing is always moving or changing depends on the speaker, place, and time of utterance. Morover, the meaning is still relevant with the context.

The main categories of deictic form or indexical expression (Yule, 1990:63) are (1) person deixis (a word that has functions as personal pronouns: you, she, he, it, etc), (2) spatial or place deixis (place or location can be deixis if that place or location is being seeing from the location of the people who are doing communication in language use in speech event: this, these, that, those, etc), (3) temporal deixis (grammatically temporal deixis can be called as adverbs of time: yesterday, today, tomorrow, etc), (4) discourse deixis(a word can be said as Discourse deixis if that word refers to certain part of that text or utterance: the following, the later, etc)and (5) social deixis (Social deixis refers to the encoding of social distinction is related to participant roles, as in the use of pronouns: $m y$ beloved friend, Mr. President, etc).

Whenever one person speaks to another, the speaker has some intention in producing the utterance, and the addressee interprets the utterance. In spite of occasional misunderstandings the hearer's interpretation often does match the speaker's intention, even when the speaker is joking or being sarcastic. If the form of an utterance does not necessarily coincide with the intended function, how does the hearer correctly know what the speaker's intention is even recognizing the speaker's humorous utterances are the sarcastic ones? Kreidler (2002:181-193) answers this question with the simple one that they know each other. They share a common background, and they are aware of sharing the common background. They may argue, insult each other, use profanity, so long as they are both used to communicating in this fashion. Speakers are less likely to 
use sarcasm and humor with strangers than with those who know them well, their utterances are more likely to be straightforward and to follow the norms for politeness, and they are ready to rephrase their messages whenever they see that misunderstanding has occurred. The speaker wants to be understood and the addressee wants to understand.

Richards et.al (1985:265) state that speech act is an utterance as a functional unit in communication. When people say that a particular bit of speech and writing is a request or an instruction or on aexemplification people are concentrating on what that piece of language is doing, or how a listener or reader is supposed to react, such entities are often called speech act (Austin and Searle in McCarthy 1991:9). Each of the stretches of language that are carrying the force of requesting, instructing and so on is seen as performing a particular act. So the approach to communicative language teaching that emphasize the functions or speech acts that pieces of language perform overlaps in an important sense with the preoccupations of discourse analysts.

Still in line Yule (1996:47) says that actions performed via utterances are generally called speech acts and in English, are commonly given more are specific labels, such as apology, complaint, compliment, invitation, promise or request. These descriptive terms for different kinds of speech acts apply to the speaker's communicative intention in producing an utterance. The speaker orally expects that his or her communicative intention will be recognized by the hearer. Both the speaker and listener are usually helped this process by the circumstances surrounding the utterance. These circumstances including other utterances are called the speech event. In many ways it is the nature of speech event that determines the interpretation of an utterance as performing a particular speech acts.

In every speech act, person can distinguish three kinds of speech acts, following Austin (in Kreidler,2002:180;181): (1) locutionary act (what is said, the utterance produced by a speaker can be called locution), (2) illocutionary act (some kind of function in mind, when the speaker produce the utterance) and (3) perlocutionnary act (the effect the utterance or written text has on the reader or listener).

Speech acts differ in their purposes, whether they deal with real or potential facts, prospective or retrospective, in the role of speaker or addressee. In these facts, and of course in felicity conditions.Kreidler (2002:183-193) divides speech acts into seven kinds: (1) assertive utterance (the purpose is to inform), (2) performativity utterance (performative utterances are valid if spoken by someone whose right to make them is accepted and in circumstances which are accepted as appropriate), (3) vindictiveutterance (speech acts in which the speaker makes an assessment or judgment about the acts of another, usually the addressee), (4) 
expressive utterance (speaker-involved), (5) directive utterance (the speaker tries to get the addressee to perform some act or refrain from performing an act), (6) commissive utterance (commit a speaker to a course of action), and (7) phatic utterance (greetings, farewells, piloted formulas such as "thank you", "you're welcome", "excuse me).

\section{RESEARCH METHOD}

This study is an ethnography research. As usual in an ethnographic research, observation and interviews are the primary methods of collecting data. These are supplemented by field notes, video-taping and check-list.

The data was analyzed using inductive analytical approach. It meant that the data analysis began while data are being gathered. Ongoing data analysis and interpretation were based on data mainly from observations. There were two main data from observation: the result of field notes and spoken language transcript.

The researcher analyzed data gathered from field notes and check lists at the end in every meeting. The data was synthesized and summarized, included any interpretation that come to mind, and recorded any questions that may be implied then find the answers. The participants (the teacher and the students) was given opportunity to respond to the initial analysis before a final draft of the data was written.

\section{FINDING}

In English teaching and learning of eleventh grade language program at Islamic Integrated Senior High School Curup in the academic year of 2013/2014, the researcher found many data in of deixis and speech acts. The examples of the dialogues among the teacer and the students are presented below:

Date : February 12, 2013

Theme: Expression of Love (Sing a song) and Narrative Text.

Time : $2 \times 45$ ' $(10.45-12.15)$

T : The whiteboard is so dirty.

S : (Someone come, stand and clean the whiteboard)

$\mathrm{T} \quad$ : For others, keep silent please! Dian, please bring your narrative text!

S8 : (He comes and stands beside her).

$\mathrm{T} \quad$ : Are you sick? (while she is looking at his coat).

S8 : (He walks to his desk and loose his coat).

$\mathrm{T} \quad$ : Ok, how many generic structures of narrative text?

S8 : Three Mam. They are orientation, complication and resolution.

$\mathrm{T} \quad$ : Ok, identify them in this story! 
S8 : (He identifies the generic structures).

T : Ok, sit down please. Next, MeiliaJayanti

S15 : Yes Mam.

\section{DISCUSSION}

From this dialogue, there are 2 speech acts and 7 deixis. The speech acts are the utterances produced by the teacher: "the whiteboard is so dirty" and "are you sick?". Furthermore, the deixis are Dian, you, Mam, they, them, Meilia Jayanti and Mam.

The researcher found 290 data in deixis and 42 data in speect acts. The data is shown in the following table.

Table 1. Deixis Found in English Teaching and Learning

\begin{tabular}{ccc}
\hline No & Kinds of Deixis & $\sum$ \\
\hline 1 & Person deixis & 168 \\
\hline 2 & Place deixis & 8 \\
\hline 3 & Temporal deixis & 32 \\
\hline 4 & Discourse deixis & 11 \\
\hline 5 & Social deixis & 71 \\
\hline & $\sum$ & $\mathbf{2 9 0}$ data
\end{tabular}

Table 1 shows the data of deixis that found in English teaching and learning. From the table, the number of deixis used by the English teacher and students are included person deixis (168), place deixis (32), temporal deixis (11), discourse deixis (8), and social deixis (71).

For the first part, the writer found that the most frequently part of deixis used by the teacher and students is person deixis (168 data). Generally, they used person deixis for plural second person (you, your). They refer to the students.

Table 2. The data of Speech Acts

\begin{tabular}{ccc}
\hline No & Kinds of Speech Acts & $\sum$ \\
\hline 1 & Assertive Utterance & 6 \\
\hline 2 & Performative Utterance & 3 \\
\hline 3 & Verdictive Utterance & 0 \\
\hline 4 & Expressive Utterance & 2 \\
\hline 5 & Directive Utterance & 25 \\
\hline 6 & Commissive Utterance & 0 \\
\hline 7 & Phatic Utterance & 6 \\
\hline & Total Number
\end{tabular}

Further, for the data of speech act, the researcher found that the most frequently type of speech acts is directive utterance. The total number of utterance 
in directive utterances is 25 data. Generally, the teacher more often used them to give command, suggestion and request. In their daily activity in the classroom, the teacher more often speaks in front of the class than the students (teacher center), that is why the data more gathered from the utterance produced by the teacher.

After doing the study, the writer got that in teaching and learning process of English in the classroom, the teacher and the students always use deixis and speech acts in their communication.

By using speech act, the teacher or the students have some intention in producing the utterance, and the addressee interprets the utterance. In spite of occasional misunderstandings the hearer's interpretation often does match the speaker's intention, even when the speaker is joking or being sarcastic.

The teacher or the students orally expects that his or her communicative intention will be recognized by the hearer. Both the speaker and listener are usually helped this process by the circumstances surrounding the utterance. These circumstances including other utterances are called the speech event. In many ways it is the nature of speech event that determines the interpretation of an utterance as performing a particular speech acts.

\section{CONCLUSION}

The writer can conclude that the teacher of English and eleventh grade students of language program at Islamic Integrated Senior High School Curup in the academic year of 2013/2014 used deixis in their daily activity at the classroom. However, the most frequently types of deixis used by them is person deixis. Therefore, The most dominant type of speech acts on English teaching and learning at Islamic Integrated Senior High School Curup in the academic year of $2013 / 2014$ is directive utterance. Generally, the teacher more often used them to give command, suggestion and request.They used deixis and speech acts almost in every moment. Because this class used teacher center, so the students used deixis and speech act only when they responded the teacher's question. 


\section{REFERENCES}

Fraenkel, Wallen. (1990). How to Design abd Evaluate Research in Education. McGraw-Hall International Edition. New York : McGraw-Hall.

Kreidler, Charles. (1998). Introducing English Semantics. New York: Routledge Taylor and Francis Group.

Levinson, Stephen C. (1983). Pragmatics. Cambridge: Cambridge University Press.

Marzulina, Leni. (2010). Lecturer's Roles and Communicative Functions in English Education Study Program Classroom of Faculty of Teacher Training and Education. UNSRI: Unpublished thesis.

McCarty, M. (1991). Discourse Analysis for Language Teachers. Cambridge: Cambridge University Press.

Nunan, David. (1992). Research Method in Language Learning: A textbook for teachers. Cambridge: Cambridge University Press.

Renkema, J. (1993). Discourse Studies: An Introduction Textbook. Amsterdam: John Benjamin Publishing Company.

Yule, George. (1996). Pragmatics: Oxford Introductions to Language Studies. Fourth Impressions. New York: Oxford University Press. 